\title{
Eksplorasi Metode Penginjilan Gereja Bala Keselamatan Sebagai Model Untuk Menjangkau Suku Kaili Da'a Di Palu Sulawesi Tengah
}

\author{
Kristiana Fitriani
}

Ketua STTII - Palu

E-mail: kristiana.anik@gmail.com

\begin{abstract}
The Kaili are a native of Palu - Central Sulawesi and are one of the target groups for sharing the gospel. According to observations and empirical data in the field, the Kaili tribe consists of three groups with a variety of cultures. The three groups are often referred to as the Da'a, the Ledo and the Tara. In terms of religion and belief, there are very striking differences. The Kaili Da'a are almost entirely Christian. The Kaili Ledo people, only a small proportion are Christians, some are Muslim and ethnic beliefs. The people of Kaili Tara are almost entirely Muslim, in fact almost none are Christians.

The existence of the majority Christian Kaili Da'a is the success of the Salvation Army church in carrying out their mission to preach the Gospel. There are a number of principles, methods and approaches that have been carried out by the Salvation Army in this regard. This makes the Salvation Army the largest church in Palu, and has the most extensive service area compared to other churches. The number of small church opened up to the mountain peaks is evidence of the success of this church in carrying out world missions.

An exploratory study of the evangelistic methods of a church that has proven successful in carrying out the mission of evangelism is very important. It is said so, because through this study one can learn how a church begins evangelistic activities, what methods it has used, what obstacles it has passed until the church has succeeded in preaching the gospel to a community group. Preaching the gospel for the Kaili tribe is something very important to do. In front of us there is still another group that has various similarities with Kaili Da'a people who do not know the gospel. The Kaili Tara people and some Kaili Ledo people also need to hear the gospel message.
\end{abstract}

The success of the Salvation Army Church in reaching the Kaili Da'a will be a case study, especially for finding effective evangelistic patterns or methods for other Kaili tribes.

The first step in this study was carried out by analyzing the Evangelical Church evangelistic model of the Kaili Da'a tribe. The results of the analysis of the model provide answers to the search for relevant methods to preach the gospel among other Kaili tribes who have not yet heard the gospel. Second, implement evangelistic strategies or patterns that are used to serve as models for evangelizing other Kaili tribal groups. It is hoped that someone or an evangelistic organization that will evangelize the Kaili tribe will not get too many difficulties, because there is already a model that can be used as a guide.

The use of methods in scientific research is very important. Therefore, the writing of this scientific paper will use two methods. The two methods are: first, library research method. The procedure adopted in this case is by reading books or articles relating to evangelism by the Salvation Church, reading books written by experts regarding the topic of evangelistic service, and reading books directly related to the topic of discussion

Second, field research methods. In this method will use participan obvervation procedures and interviews with people involved in Salvation Army church evangelism activities. In addition, by looking for reliable data regarding the results of evangelism conducted by the alvation Army stionnaires containing questions related to the topic of discussion will be distributed to Salvation Army church leaders and activists directly related to the evangelistic ministry and will be returned to the author for further processing.

From the field research through the questionnaire it was concluded that the most instrumental aspect in evangelizing the Kaili Da'a tribe was through the visit of officers, then personal 
evangelism by the officers and also through the testimony of the Salvation Church. It is evident that the service of the officers has a very important role in evangelizing the Kaili tribe.

That is why the author advised the Salvation Army to improve the quality of officers. Provisioning and training as well as increasing the resources of the officers should be carried out in a consistent and directed activity.

In general, the authors see that the Salvation Army succeeded in introducing and guiding the Kaili Da'a community to accept the Lord Jesus as their personal Lord and Savior. Furthermore, the authors advise that these service activities be continued in a directed and consistent manner. In addition, pastoral care of the congregation that has accepted the Lord Jesus needs to be improved so that the congregation's understanding of Jesus grows and the Church becomes a strong believer in facing all the challenges of life.

Keywords: Salvation Army, Church, Evangelism.

\section{PEDAHULUAN}

Istilah Amanat Agung merupakan satu istilah yang tidak asing lagi di kalangan orang percaya. Perintah yang disampaikan oleh Tuhan Yesus sesaat sebelum kenaikan-Nya ke surga itu "terus dikerjakan oleh para rasul sejak hari Pentakosta, ketika Roh Kudus dicurahkan ke atas mereka" dan diteruskan oleh para pengikut Kristus sampai hari ini.

Perintah Yesus itu tegas, jelas dan ditujukan kepada semua orang percaya, sebagaimana Imanuel Sukardi menyebutkan bahwa perintah itu merupakan panggilan bagi semua orang percaya. Dia mengatakan bahwa, "Begitu para murid percaya, barulah perintah ini diberikan. Jadi perintah ini ditujukan kepada mereka karena mereka percaya bukan karena mereka menjadi murid. Jelas perintah ini ditujukan bagi mereka yang telah percaya, maka salah besar kalau ini ditafsirkan hanya untuk ke-12 murid. Dengan demikian amanat ini bagi setiap orang percaya, murid atau bukan murid-Nya. Maka dari itu perintah tersebut berlaku dan ditujukan kepada setiap orang percaya di sepanjang zaman."

Matthew E. Carlton menyebutkan mananat agung itu sebagai "Perintah Yesus yang terakhir kepada murid-murid-Nya" dan isinya adalah perintah untuk "menjadikan semua bangsa dan suku bangsa menjadi muridmurid Yesus, dengan tekanan semua suku di seluruh dunia." Bukan hanya persoalan supaya beragama Kristen dan dibaptis saja.

Dewasa ini, ada banyak tafsiran berkenaan dengan isi dan pelaksanaan Amanat Agung tersebut. Ada yang memahaminya sebagai perintah untuk menjadikan semua orang menjadi orang Kristen, ada pula yang memahaminya sebagai tugas gereja untuk memperkenalkan Yesus dan anugerah keselamatan kepada semua orang.

Berkenaan dengan hal ini, Charles F. Pfeiffer dan Everett F. Harrison dalam salah satu buku yang disuntingnya mengatakan bahwa yang dimaksud dengan perintah "jadikan semua bangsa murid-Ku" adalah "tugas untuk mendaftarkan orang di bawah ketuhanan Kristus."

Dalam Alkitab terjemahan Bahasa Indonesia Sehari-hari (BIS) dijelaskan bahwa yang dimaksud dengan menjadikan semua bangsa menjadi murid Kristus adalah menjadikan semua orang menjadi pengikut Kristus.

Dengan mengacu pada keteranganketerangan tersebut maka dapatlah disimpulkan bahwa perintah Yesus yang terakhir, sebelum Dia terangkat ke surga adalah perintah untuk menjadikan semua orang atau semua suku bangsa dari seluruh dunia ini untuk menjadi pengikut-Nya, menjadi orang-orang yang mengakui Yesus sebagai Tuhan dan Juruselamat mereka.

\section{LATAR BELAKANG}

Suku Kaili, yang merupakan penduduk asli Palu - Sulawesi Tengah merupakan salah satu kelompok sasaran pemberitaan kabar sukacita. Menurut pengamatan dan data empiris di lapangan, suku Kaili ini terdiri dari berbagai kelompok dengan berbagai ragam budaya.

Di antara semua selompok itu, ada tiga kelompok yang besar. Tiga kelompok itu sering disebut dengan sebutan orang Da'a, orang Ledo dan orang Tara. Orang Kaili Da'a 
menempati bagian gunung-gunung yang ada di Palu, sampai masyarakat menjulukinya sebagai orang gunung. Peradaban mereka tergolong sederhana dan primitif. Orang Kaili Ledo menempati daerah-daerah di bawah gunung dengan peradaban yang sedikit lebih maju, sedangkan orang Kaili Tara menempati daerah perkotaan. Bahasa ketiga kelompok ini sama, hanya berbeda logat. Dari segi sosial budaya, ketiganya memiliki kemiripan.

Dalam hal agama dan kepercayaan, terdapat perbedaan yang sangat menyolok. Orang Kaili Da'a hampir seluruhnya beragama Kristen. Orang Kaili Ledo, hanya sebagian kecil beragama Kristen, sebagian lainnya muslim dan kepercayaan suku. Orang Kaili Tara hampir seluruhnya beragama muslim, bahkan hampir tidak ada yang beragama Kristen.

Tidak bisa dipungkiri bahwa eksistensi orang Kaili Da'a yang mayoritas Kristen itu merupakan keberhasilan gereja Bala Keselamatan dalam menjalankan misi pemberitaan Injil kepada mereka. Menurut sejarah perkembangan gereja Bala Keselamatan di Sulawesi Tengah, utusan Injil dari gereja Bala Keselamatan yang diutus untuk menjangkau suku Kayeli mulai masuk di permulaan abad ke-20. Waktu itu, Almarhum Kolonel William Harries diutus dari Kantor Pusat di New York untuk menjangkau suku tersebut. Kolonel William Harries menuturkan bahwa kondisi suku Kaili saat itu masih sangat terbelakang. Banyak wilayah yang belum tersentuh, tidak ada jalan raya, dan kondisi daerah yang masih berhutan-hutan. Dia mengatakan demikian:

Suku Kayeli, sampai permulaan abad ini (maksudnya abad ke-20), hidup dengan cara yang biadab seperti apa yang disebut "berburu kepala". Walaupun ada kenyataan yang menakutkan ini, mereka sesungguhnya orangorang yang sederhana, ramah dan belum banyak mendapat pengaruh-pengaruh luar. Mereka rata-rata berwatak kuat, tetapi mereka hidup sangat terbelakang.

Kondisi primitif itu terlihat dalam banyak hal. Dari masalah makanan, pakaian, tempat tinggal, cara pergaulan, dan juga segisegi kehidupan yang lain. Mereka belum mengenal waktu atau jam. Budaya mereka sangat sederhana dan juga banyak hal yang unik dan aneh. Keunikan dan keanehan itu terlihat dalam acara-acara adat, misalnya adanya kebiasaan mengikir gigi yang dilakukan para wanita muda.

Minat mereka dalam hal agama atau kepercayaan terhadap Tuhan sangat rendah. Mereka orang-orang yang hidup santai, hanya memandang hari ini dan hidup apa adanya. Mereka tidak berpikir panjang untuk masa yang akan datang, cukuplah memikirkan masa kini saja. Sehubungan dengan hal itu, Melattie menuturkan:

"Mereka tak pernah memperhitungkan waktu dengan seksama, dan hidup santai dan dekat dengan alam. Sementara itu mereka secara samar-samar memahami pengertian kekal dengan menganut kepercayaan kepada roh-roh halus. Mereka menyembah roh-roh halus, umumnya pada saat diadakan pestapesta dan anak-anak yang mereka pilih untuk bertindak sebagai imam dalam acara adat ini. Mereka tidak memiliki instink yang kuat untuk beragama, sehingga tak mengherankan kalau berhala-berhala mereka tak terawat dan dilalaikan, kecuali pada saat-saat kesulitan.”

Tetapi uniknya, saat ini suku Kaili khususnya orang Da'a hampir semuanya adalah orang percaya. Mereka umumnya menjadi anggota gereja Bala Keselamatan. Melattie mencatat bahwa "ketika mereka mulai bertobat dan percaya kepada Tuhan umumnya mereka menjadi orang-orang Bala Keselamatan yang militan."

Melihat keberhasilan yang telah dicapai oleh gereja Bala Keselamatan, khususnya dalam menjangkau orang $\mathrm{Da}^{\prime} \mathrm{a}$, penulis menduga pasti ada sejumlah prinsip, metode dan pendekatan-pendekatan yang telah dilakukan oleh gereja Bala Keselamatan dalam menjangkau orang Da'a. Keberhasilan gereja Bala Keselamatan tersebut telah menempatkannya sebagai gereja yang paling besar di Palu, serta memiliki daerah pelayanan yang paling luas dibandingkan gereja-gereja yang lain. Gereja Bala Keselamatan lah yang memiliki pos-pos pelayanan sampai ke puncak-puncak gunung, yang belum dijamah oleh utusan-utusan Injil lainnya.

Studi eksplorasi metode penginjilan dari suatu gereja yang terbukti berhasil menjalankan misi pemberitaan Injil menjadi hal yang sangat penting. Dikatakan demikian, sebab melalui studi ini seseorang dapat belajar bagaimana sebuah gereja memulai kegiatan penginjilan, metode-metode apa yang telah dipakainya, kendala-kendala apa yang telah 
dilewatinya sampai gereja tersebut berhasil dalam memberitakan Injil kepada suatu kelompok masyarakat.

Pemberitaan Injil bagi suku Kaili merupakan sesuatu yang sangat penting untuk dilakukan. Di hadapan kita masih tersisa kelompok lain yang memiliki berbagai kesamaan dengan orang Kaili Da'a yang belum mengenal Injil. Orang Kaili Tara dan sebagian orang Kaili Ledo perlu juga untuk mendengar berita Injil. Keberhasilan gereja Bala Keselamatan dalam menjangkau orang Kaili Da'a akan menjadi suatu studi kasus, terutama untuk menemukan pola atau metode penginjilan yang efektif bagi suku Kaili yang lain.

\section{FOKUS PENELITIAN}

Fokus penelitian yang dilakukan oleh penulis dalam menyusun karya tulis ini mencakup pelayanan pemberitaan kabar sukacita yang dilakukan oleh Gereja Bala Keselamatan terhadap suku Kaili Da'a. Dalam penelitiannya pun, hanya akan meneliti tentang metode atau pola yang dipakai oleh gereja tersebut, secara khusus dalam menjangkau suku Kaili Da’a.

\section{RUMUSAN MASALAH}

Keberhasilan suatu pelayanan penginjilan ditentukan dari hasil yang dicapai baik secara kuantitas maupun kualitas. Kuantitas di sini berarti dilihat dari jumlah orang yang menerima Kristus sebagai Tuhan dan Juruselamat. Sedangkan segi kualitas dilihat dari kedewasaan iman setiap orang yang telah menerima Kristus sebagai Tuhan dan Juruselamat itu. Selain itu, keberhasilan suatu pelayanan penginjilan terhadap suatu komunitas tertentu dilihat dari prosentase pengikut Kristus dalam komunitas itu.

Melalui pelayanan penginjilan Gereja Bala Keselamatan dari segi prosentase lebih dari 50\% dari suku Kaili Da'a adalah pengikut Kristus. Namun demikian secara kualitatif membutuhkan penelitian tersendiri, apakah pelayanan penginjilan gereja Bala Keselamatan terhadap suku Kaili Da'a telah berhasil.

Dengan memperhatikan hal-hal tersebut di atas, maka rumusan masalah terhadap penelitian ini adalah: Bagaimanakah metode pemberitaan kabar sukacita yang diterapkan oleh Gereja Bala Keselamatan pada suku Kaili Da'a?

\section{METODE PENELITIAN}

Penggunaan metode di dalam penelitian karya ilmiah sangatlah penting. Oleh karena itu, penulisan karya ilmiah ini akan menggunakan dua metode. Kedua metode tersebut yakni : pertama, metode riset pustaka. Prosedur yang ditempuh dalam hal ini yaitu dengan cara membaca buku-buku atau artikel yang berkenaan dengan penginjilan yang dilakukan gereja Bala Keselamatan, membaca buku-buku yang ditulis para pakar berkenaan dengan topik pelayanan penginjilan, serta membaca buku-buku yang berkaitan langsung dengan topik pembahasan.

Kedua, metode riset lapangan. Dalam metode ini akan menggunakan prosedur PO dan wawancara dengan orang-orang yang terlibat dalam kegiatan penginjilan gereja BK. Selain itu juga dengan mencari data-data yang dapat dipercaya berkenaan dengan hasil penginjilan yang dilakukan oleh gereja Bala Keselamatan. Quesioner yang berisikan dengan pertanyaan-pertanyaan sehubungan dengan topik pembahasan akan dibagikan kepada para pemimpin dan aktivis gereja Bala Keselamatan yang terkait langsung dengan pelayanan penginjilan dan akan dikembalikan kepada penulis untuk proses selanjutnya.

Metode riset lapangan dilakukan dengan beberapa cara yaitu: pertama, metode penelitian eksploratif, yaitu metode yang digunakan dalam menggali pengetahuan untuk pengenalan dan pemahaman tentang metode pemberitaan Injil yang dilakukan oleh gereja Bala Keselamatan. Kedua, metode penelitian eksplanatif, yakni menjelaskan ciri atau strategi tertentu yang dapat digunakan untuk melaksanakan pemberitaan Injil. Ketiga, metode penelitian evaluatif yaitu untuk mempermudah mengambil suatu keputusan sehubungan dengan keunggulan dari beberapa alternatif tindakan setelah melakukan evaluasi terhadap pelaksanaan suatu kegiatan.

\section{TUJUAN PENELITIAN}

Tujuan penelitian dalam tesis ini adalah pertama, untuk menganalisa model penginjilan gereja Bala Keselamatan terhadap suku Kaili Da'a. Hal-hal yang menjadi tujuan penelitian dalam hal ini adalah: pertama, hal- 
hal yang perlu disiapkan sebelum memulai pelayanan penginjilan terhadap suku Kaili. Kedua, strategi atau pola penginjilan yang dipakai. Ketiga, target awal dalam pelayanan ini.

Hasil analisa atas model itu memberi jawaban pada pencarian metode yang relevan untuk memberitakan Injil di kalangan sukusuku Kaili lain yang belum mendengar Injil. Diharapkan seseorang atau suatu organisasi penginjilan yang akan melakukan penginjilan terhadap suku Kaili tidak mendapat banyak kesulitan, sebab telah ada model yang dapat digunakan sebagai pedoman.

\section{DEFINISI ISTILAH}

Penelitian ini mengambil judul "Eksplorasi Metode Penginjilan sebagai Model untuk Menjangkau Suku Kaili Da'a di Gereja Bala Keselamatan." Beberapa istilah yang dipakai dalam judul tersebut akan dijelaskan dalam bagian ini. Kata Eksplorasi, merupakan kata yang berasal dari bahasa Inggris "explore" yang artinya menjelajahi, menyelidiki, atau memeriksa." Kata tersebut telah diadopsi dalam bahasa Indonesia, bahkan sudah cukup lazim untuk digunakan. Dalam Kamus Besar Bahasa Indonesia, kata eksplorasi berarti "penjelajahan lapangan dengan tujuan memperoleh pengetahuan lebih banyak." Kata ini sering dipakai dalam dunia ilmu pengetahuan, secara khusus dalam masalah pertambangan.

Prinsipnya, kata itu menunjukkan pada suatu kegiatan atau usaha untuk mendapatkan hasil atau keterangan yang banyak dengan cara menganalisa, meneliti dan menggali dari berbagai sumber yang ada. Pemakaian kata tersebut dalam penelitian ini menunjukkan bahwa akan menggali keterangan sebanyakbanyaknya metode pemberitaan Injil yang dilakukan gereja Bala Keselamatan di Sulawesi Tengah, khususnya terhadap orang Kaili Da'a.

Kata metode berarti "cara teratur yang digunakan untuk melaksanakan suatu pekerjaan agar tercapai sesuai dengan yang dikehendaki; cara kerja yang konsisten untuk memudahkan pelaksanaan suatu kegiatan guna mencapai tujuan yang ditentukan." Dalam hal ini yang dimaksudkan adalah cara gereja Bala Keselamatan dalam melaksanakan penginjilan bagi orang Da'a hingga mencapai hasil yang memuaskan.
Kata penginjilan, Gereja Bala Keselamatan dan Kaili Da'a akan dibahas secara panjang lebar dalam bab-bab selanjutnya. Relevan artinya "kait mengait, bersangkut paut, dan berguna secara langsung."

\section{AMANAT AGUNG}

Istilah pemberitaan Injil merupakan istilah yang tidak asing lagi di telinga banyak orang. Di kalangan orang percaya, istilah tersebut secara umum dimengerti sebagai usaha untuk memberitakan keselamatan di dalam Yesus dan dilakukan dengan cara menyampaikan firman Tuhan.

Di kalangan orang yang belum percaya terhadap Yesus, istilah tersebut dimengerti sebagai usaha untuk mengkristenkan orang lain. Pemahaman seperti itulah yang sering menjadi persoalan karena dianggap mengkuatirkan agama atau kepercayaan tertentu.

Defenisi yang dibuat oleh George W. Peters tentang pemberitaan Injil adalah:

"Penginjilan menunjuk kepada fase permulaan dari pelayanan Kristen itu adalah proklamasi dengan kuasa Injil Yesus Kristus seperti yang dinyatakan dalam Alkitab melalui kata-kata yang relevan dan jelas dan dengan cara mempersuasi disertai tujuan yang pasti untuk menghasilkan petobat-petobat. Penginjilan adalah presentasi- penetrasipenyerapan- konfrontasi yang tidak hanya sukses dalam menyampaikan informasi namun menuntut keputusan. Itu adalah presentasi Injil untuk meyakinkan orang yang tidak percaya menjadi percaya dalam Yesus Kristus."

John Stoot menambahkan defenisi penginjilan adalah: "memberitakan Yesus Kristus dalam kuasa Roh Kudus, sehingga orang mempercayakan diri kepada Allah melalui yesus, menerima-Nya sebagai Juruselamat mereka dan melayani Dia sebagai Raja di dalam persekutuan jemaatnya."

Sebagaimana telah dijelaskan dalam bagian sebelumnya, inti Amanat Agung adalah pemberitaan Injil. Namun demikian, di kalangan orang percaya sendiri praktek pemberitaan Injil masih rancu. Beberapa kelompok menekankan pelayanan sosial sebagai pelayanan pemberitaan Injil, sehingga istilah social gospel menjadi sangat populer. 
Penginjilan atau evangelism berasal dari kata dalam bahasa Yunani yakni euaggelion (euanggelion), yang berarti good news atau kabar baik. Kabar baik yang dimaksudkan adalah Injil yang berisi berita keselamatan, berita pengampunan, berita pendamaian dan berita pengudusan bagi orang berdosa.

Kabar baik adalah anugerah yang dapat diperoleh melalui Yesus Kristus, dan dengan iman kepada-Nya orang berdosa mendapatkan hidup yang kekal. Dari kata euaggelion ini muncul kata kerja euangelizo yang berarti to bring or announce glad tidings atau to proclaim, to declare good news of the Kingdom atau membawa kabar baik.

Kabar baik atau berita keselamatan adalah berita mengenai kematian dan kebangkitan Kristus bagi orang berdosa. Yesus mati ganti orang berdosa, Ia mencurahkan darah-Nya untuk menebus dosadosa manusia. Ia bangkit karena maut tidak berkuasa atas-Nya. Yesus telah naik ke surga, duduk di sebelah kanan Allah, dan menjadi juru safaat bagi manusia. Ia telah mendamaikan manusia dengan Allah, dan membawa manusia kepada Allah.

Menurut Rasul Paulus, Injil adalah kekuatan Allah yang menyelamatkan semua manusia (Rm.1:16). Karena Injil itulah maka Paulus diselamatkan dari murka Allah. Karena anugerah-Nya, Paulus menerima panggilan dari Yesus dalam perjalannannya menuju Damsyik. Panggilan ini adalah panggilan pertobatan melalui Injil dan panggilan untuk memberitakan Injil kepada sesamanya.

Injil adalah kabar baik yang harus disampaikan kepada semua orang. Injil juga adalah anugerah Allah kepada manusia, sehingga tidaklah bijaksana jika ada pemaksaan kehendak dalam pemberitaan Injil.

Arie de Kuiper memakai istilah Ilmu Pekabaran Injil atau Missiologia untuk menjelaskan masalah pemberitaan Injil. Nampaknya dia memasukkan pemberitaan Injil sebagai suatu ilmu, yaitu ilmu pengetahuan mengenai pemberitaan Injil Yesus Kristus. Jika pemberitaan Injil merupakan suatu ilmu, maka ada prosedur-prosedur tertentu yang diterapkan dalam mencapai keberhasilan. Ilmu adalah sesuatu yang dapat dipelajari, dianalisa dan dikembangkan sesuai dengan kondisi yang ada.

Jika Arie de Kuiper memasukkan pemberitaan Injil dalam kelompok ilmu, Makmur Halim menyatakan bahwa pemberitaan Injil adalah suatu seni. Dia menjelaskan bahwa "memberitakan Injil adalah suatu seni yang harus ditekuni dan dipersiapkan pemberitaannya dengan baik."

Istilah missiologia dahulu hanya dipakai oleh para ahli teologia Roma-Katolik, namun sekarang sudah diterima juga oleh teologteolog Protestan di bidang ini. Berkenaan dengan istilah missiologia ini, Kuiper selanjutnya menyatakan bahwa ada beberapa macam missio, yaitu Missio Ecclesiae (pengutusan gereja), Missio Apostolorum (pengutusan para rasul), Missio Christi (pengutusan Kristus) dan Missio Dei (keseluruhan pekerjaan Allah untuk menyelamatkan dunia).

Nyatalah sudah bahwa pemberitaan Injil atau penginjilan merupakan usaha untuk memberitakan Injil atau kabar baik, yaitu adanya keselamatan di dalam Yesus. Yesus telah mati, bangkit dan naik ke surga dalam rangka karya penyelamatan bagi manusia. Penginjilan belumlah dikatakan penginjilan jika belum ada pemberitaan tentang Yesus sebagai satu-satunya jalan menuju keselamatan.

\section{KEPERCAYAAN MASYARAKAT SUKU KAILI}

Mengenai kepercayaan yang hidup dalam masyarakat dapat dikemukakan antara lain: kepercayaan yang masih hidup dalam masyarakat kelihatan dalam bebagai upacara adat dalam aspek daur hidup, upacara adat dalam bidang pertanian dan adat kemasyarakatan lainnya.

Misalnya masih ada kepercayaan dewadewa, kepercayaan kepada benda-benda sakti, orang keramat dan simbol-simbol religi lainnya. Pada dasarnya kepercayaan yang masih ada ialah kepercayaan kepada dewadewa yang disebut karampua, seperti karampua nulangi dan karampua ntana (penguasa langit dan penguasa bumi).

Kepercayaan kepada To Manuru, yaitu kepada orang sakti yang menjelma dari kayangan sebagai titisan dewa, tidak dikenal asal-usulnya karena menjelma dengan tibatiba melalui berbagai media seperti kayu besar, bambu kuning. Kepercayaan kepada mahluk-mahluk halus yang dianggap mendiami seluruh wilayah. Mereka percaya bahwa mahluk halus itu merupakan sumber segala bencana, gangguan hidup (penyebab 
penyakit, membawa kegagalan panen dan hasil pertanian lainnya).

Demikian pula kepercayaan kepada kekuatan-kekuatan alam (benda-benda alam) yang dapat dijadikan penangkal untuk mengusir penyakit dan bebagai bencana lainnya, sehingga timbullah berbagai ilmu-ilmu hitam (black magic) seperti doti.

Dari kepercayaan-kepercayaan inilah timbul berbagai kelakuan manusia dalam kaitannya dengan kepercayaan itu. Dikenal misalnya simbol-simbol berupa azimat (simasima) upacara tolak bala (motula bala) dan ini nampak dalam upacara-upacara adat.

Perbuatan-perbuatan yang dilarang dalam kepercayaan di sini adalah meremehkan atau tidak menaati tata upacara adat yang diharuskan dan berlaku secara umum dilingkungan masyarakat seperti upacara daur hidup, upacara dalam bidang pertanian, uapacara selamatan lainnya.

Sedangkan perbuatan-perbuatan yang diharuskan ialah mengikuti secara tertib setiap aturan dan upacara adat yang berlaku, sperti melaksanakan upacara-upacara adat sesuai ketentuan, melaksanakan kerja gotong royong (sintuwu) dalam setiap pelaksanaan adat dan upacara dalam segala segi kehidupan, membantu orang lain mnyediakan alat-alat dan bahan yang diperlukan dalam upacara-upacara itu serta selalu bersedia sebagai peserta upacara yang baik.

Bagi mereka yang melakukan perbuatan yang dilarang oleh kepercayaan ini, diberi sangsi berupa hukuman sosial dimana mereka itu dipencilkan dalam setiap kegiatan yang ada, jadi merupakan beban psikologis yang cukup berat. Biasanya hukuman sosial tersebut dapat merobah sikap dan tingkah laku seseorang dan ia akan berusaha sebaik mungkin untuk menghayati dan mengamalkan kepercayaan yang hidup, tumbuh dan berkembang dalam masyarakat lingkungannya.

Perbuatan-perbuatan agama yang dilarang adalah semua larangan yang diajarkan oleh agama itu sendiri, seperti mencuri, menipu, berbohong, behati dengki, egoistis, iri hati, sombong dan seluruh perbuatan-perbuatan yang bertentangan dengan ajaran agama. Sedangkan perbuatan-perbuatan yang diharuskan adalah menolong sesama manusia, kasih-mengasihi, mengabdi kepeda Tuhan Yang Maha Esa dan mempertebal ketaqwaan sesuai dengan ajaran agama. Tegasnya menjauhi segala larangan dan mematuhi seluruh ketentuan dan ajaran agama.

Bagi orang yang melakukan perbuatan yang dilarang sanksinya adalah cemoohan dari masyarakat, bahkan sudah dicap sebagai orang yang meremehkan prinsip dasar ajaran agama itu sendiri. Kalau cemoohan itu sudah meluas dalam masyarakat lingkungannya, dapat dipastikan bahwa yang bersangkutan akan dibebani beban moral yang cukup berat, yaitu berupa perasaan dosa besar. Apalagi kalau yang bersangkutan sudah tidak perna didekati,tidak diajak pergaulan

Dan kegiatan-kegiatan kemasyarakatan lainnya. Sanksi ini yang dapat dilihat, tetapi yang pasti cukup banyak akibat dari sanksi itu, seperti adanya perasaan tidak tentram, gelisah dalam hidup dan semacamnya. Sedangkan sanksi sesudah mati adalah azab dan siksaan Tuhan yang tiada taranya.

Apabila sanksi ini benar-benar dapat dirasakan dan menghujam dalam lubuk hati yang bersangkutan, maka lambat atau cepat akan mempengaruhi jiwanya, sehingga mengguga yang bersangkutan untuk bertobat, merobah sikap dan tingkah-lakunya untuk mengikuti, menghayati dan mengamalkan agama sebaik-baiknya.

\section{SIMPULAN}

Tidak seorang pun di dunia ini yang tidak berdosa. Alkitab menegaskan bahwa semua manusia telah berbuat dosa dan kehilangan kemuliaan Allah. Kondisi berdosa tersebut menuntut semua manusia membutuhkan anugerah keselamatan. Itulah sebabnya kegiatan pemberitaan kabar sukacita harus dilakukan dengan serius, terarah dan konsisten.

Perintah Yesus yang terakhir, sebelum Dia terangkat ke surga adalah perintah untuk menjadikan semua orang atau semua suku bangsa dari seluruh dunia ini menjadi pengikut-Nya, menjadi orang-orang yang mengakui Yesus sebagai Tuhan dan Juruselamat mereka. Pemberitaan Injil atau penginjilan merupakan usaha untuk memberitakan Injil atau kabar baik, yaitu adanya keselamatan di dalam Yesus. Yesus telah mati, bangkit dan naik ke surga dalam rangka karya penyelamatan bagi manusia. Penginjilan belumlah dikatakan penginjilan jika belum ada pemberitaan tentang Yesus 
sebagai satu-satunya jalan menuju keselamatan.

Berdasarkan penelitian lapangan yang dilakukan, khususnya melalui pertanyaanpertanyaan yang disajikan, maka diperoleh hasil bahwa banyak anggota Jemaat gereja Bala Keselamatan, khususnya dari suku Kaili Da'a yang menerima Tuhan Yesus sebagai Tuhan dan Juruselamat melalui beberapa aspek dalam pelayanan gereja Bala Keselamatan.

Aspek-aspek itu terdiri dari puji-pujian, pelayanan firman Tuhan, perkunjungan para opsir Bala Keselamatan, pelayanan social dengan mendirikan Panti Asuhan Bala Keselamatan dan rumah sakit dan juga penginjilan pribadi yang dilakukan para opsir gereja Bala Keselamatan.

Dari penelitian lapangan melalui kuisioner didapatkan kesimpulan bahwa aspek yang paling berperan dalam penginjilan terhadap suku Kaili Da'a adalah melalui perkunjungan para opsir, kemudian penginjilan pribadi yang dilakukan para opsir dan juga melalui kesaksian yang dilakukan gereja Bala Keselamatan. Nyatalah bahwa pelayanan para opsir memiliki peran yang sangat penting dalam penginjilan terhadap suku Kaili.

Itulah sebabnya penulis memberi saran kepada gereja Bala Keselamatan untuk meningkatkan kualitas para opsir. Pembekalan dan pelatihan serta peningkatan sumber daya para opsir hendaknya menjadi kegiatan yang dilakukan secara konsisten dan terarah.

Dugaan awal penulis yang mencantumkan bahwa pelayanan penginjilan terhadap suku Kaili Da'a dilakukan melalui pendekatan terhadap suku tersebut dengan ditunjang peyediaan sarana pelayanan sosial seperti rumah sakit, sekolah dan panti asuhan itu terbukti.

Melalui wawancara penulis mendapatkan jawaban bahwa perkunjungan dan penginjilan pribadi para opsir Bala Keselamatan memiliki peran yang sangat besar dalam kegiatan penginjuilan gereja Bala Keselamatan.

Secara umum penulis melihat bahwa gereja Bala Keselamatan berhasil dalam memperkenalkan serta menuntun masyarakat Kaili Da'a untuk menerima Tuhan Yesus sebagai Tuhan dan Juruselamat pribadi. Selanjutnya, penulis memberi saran supaya kegiatan pelayanan tersebut diteruskan secara terarah dan konsisten. Selain itu, penggembalaan terhadap jemaat yang sudah menerima Tuhan Yesus perlu terus ditingkatkan sehingga pemahaman jemaat terhadap Yesus semakin bertumbuh dan Jemaat menjadi orang percaya yang tangguh dalam menghadapi semua tantangan kehidupan.

\section{DAFTAR PUSTAKA}

[1] Achard, R. Martin. Israel et Les Nations. London: Neuchaetel, 1969.

[2] Barclay, William. Pemahaman Alkitab Setiap Hari Matius Pasal 1-10. Diterjemahkan oleh Wismoadi Wahono. Jakarta : BPK Gunung Mulia, 1995.

[3] Barna, George. The Power of Vision. Diterjemahkan oleh Rina Letedara. Jakarta: Metanoia Publishing, 1992

[4] Berkhof, H. dan I.H Enklaar. Sejarah Gereja. Jakarta BPK Gunung Mulia, 1967.

[5] Boejdoewono, Noegroho. Pengantar Statistik Ekonomi dan Perusahaan. Yogyakarta: Unit Penerbit dan Percetakan AMP YKPN, 1987.

[6] Brouwer, Melattie. 60 tahun Bala Keselamatan di Sulawesi Tengah. Bandung: Bala Keselamatan, 1977.

[7] Buzzel, Sid S. "Proverb." Dalam The Bible Knowledge Commentary, Old Testament. Disunting oleh John F. Walvoord dan Roy B. Zuck. Wheaton, Illinois: SP Publications, 1985.

[8] Carlton, Matthew E. Injil Matius. Jakarta : Yayasan Kartidaya, 2002.

[9] Charles F. Pfeiffer. "Matius." Dalam The Wycliffe Bible Commentary, Jilid 3. Disunting oleh Charles F. Pfeiffer dan Everett F. Harrison. Diterjemahkan oleh Penerbit. Malang : Yayasan Penerbit Gandum Mas, 2001.

[10] Coleman, Robert E. Rencana Agung Penginjilan. Diterjemahkan oleh G. J. Tiendas dan W. Stanley Heath. Bandung: Kalam Hidup, t.t.

[11] Dixon, R. Tafsiran Kisah Para Rasul. Surabaya: YAKIN, t.t. 
[12] Echols, John M dan Hasan Shadily. Kamus Inggris-Indonesia, Jakarta : PT Gramedia, 2000.

[13] Fances, Eddy. Gereja Yang Mulia dan Misioner. Jakarta: YASINTA, 2000.

[14] Faot, Agustinus, et al. "Bertahan Sampai Kesudahan Akan Diselamatkan." Journal KERUSSO 4.1 (2019): 15-25.

[15] Graham, Billy. Beritakan Injil: Standar Alkitabiah bagi Penginjil. Diterjemahkan oleh Doreen S. Widjana. Yogyakarta: Yayasan ANDI, 1992.

[16] Halim, Makmur. Model-Model Penginjilan Yesus: Suatu Penerapan Masa Kini. Malang: Gandum Mas, 2003.

[17] Hasan, Alwi. Penyunting. Kamus Besar Bahasa Indonesia. Jakarta: Balai Pustaka, 2003.

[18] Henrichsen, Walter A. Cara Melatih Murid Kristus. Diterjemahkan oleh Ganda Wargasetia. Bandung: Kalam Hidup, t.t.

[19] Heath, W. Stanley. Penginjilan dan Pelayanan Pribadi. Surabaya: YAKIN, t.t.

[20] Koentjoroningrat. Metodologi Penelitian Masyarakat. Jakarta: PT Gramedia, 1977.

[21] Kuiper de, Arie. Missiologia. Jakarta: BPK Gunung Mulia,2003.

[22] Lovett, C. S. Bersaksi dengan Mudah. Diterjemahkan oleh E.M. Tumudo dan B.L Tobing. Bandung: Kalam Hidup, t.t.

[23] Ndjau, Tebun dan Urbanus Selan. Rahasia Pertumbuhan Gereja Korea. Kalimantan: GKII Wilayah Kalimantan, 1998.

[24] Permana, Surja, et al. "Memorizing Bible Verses with the Association Method of Quantum Learning in Sunday School." Journal Didaskalia 2.1 (2019): 1-5.

[25] Peters, George W. A Biblical Theology of Missions. Chicago: Moody Press, 1984.

[26] Prasetyo, Widi, et al. "Measuring the Quality of God's Servants According to Acts 6:
3 At the Surabaya City Tabernacle Pentecostal Church." Journal KERUGMA 2.1 (2019): 2433.

[27] Purba, Nursenta Dahliana. "Keillahian Yesus Kristus." Journal Kerusso 1.2 (2016): 15-21.

[28] Rumiyati, Rumiyati, et al. "Pengaruh Kepemimpinan Hamba Tuhan Dalam Pertumbuhan Kerohanian Jemaat Gereja GPdI 'Zion'Krebet, Tembalang, Wlingi-Blitar." Journal Kerusso 3.2 (2018): 9-19.

[29] Schlunk, M. Die Weltmission der Kirche Christi. Hamburg: Hamburg Press, 1925.

[30] Stott, John. Fundamentalisme dan Penginjilan. Diterjemahkan oleh Gerrit Tindas dan Stanley Heath. Bandung: Kalam Hidup, t.t.

[31] Sukardi, Imanuel. Pedoman Penanaman Gereja Baru Masa Kini. Solo: Sekolah Tinggi Theologia Indonesia Surakarta, 2004.

[32] Sumanto. Metodologi Penelitian Sosial dan Pendidikan: Aplikasi Metode Kuantitatif dan Statitiska dalam Penelitian. Yogyakarta: Andi Ofset, 1995.

[33] Suprapto, J. Metode Riset: Aplikasinya dalam Pemasaran. Jakarta: Rineka Cipta, 1997.

[34] Thiessen, Henry C. Teologi Sistematika. Direvisi oleh Vernon D. Doerksen. Diterjemahkan oleh Penerbit. Malang: Gandum Mas, 1992.

[35] Tooley, Ross. Celakalah Aku Jika tidak Memberitakan Injil: Sebuah Panduan Praktis untuk Penginjilan Pribadi. Diterjemahkan oleh Penerbit. Yogyakrta: Yayasan ANDI, 1996.

[36] Venema,H. Injil Untuk Semua Orang. Jakarta: Yayasan Komunikasi Bina Kasih, 1997.

[37] Vine, W.E. Vine's Expository Dictionary of New Testament Words. Iowa Falls: Riverside Book and Bible House, t.t. 
KERUSSO, VOLUME 4 NUMBER 2 SEPTEMBER 2019

[38] Wagner, C. Peter. Gereja Saudara dapat Bertumbuh. Diterjemahkan oleh Penerbit. Malang: Gandum Mas, 1997.

[39] Gempa Gereja: Bagaimana Reformasi Apostolik Baru Mengguncang Gereja. Diterjemahkan oleh Jenny Elfrida Naibabo dan Yahya Kristiyanto. Jakarta: Nafiri Gabriel, 2000.

[40] Warren, Rick. Pertumbuhan Gereja Masa Kini. Diterjemahkan oleh Penerbit. Malang: Gandum Mas, 1999. 